Article

\title{
The Virtuous Circle of Sustainable Welfare as a Transformative Policy Idea
}

\author{
Tuuli Hirvilammi (D)
}

Faculty of Social Sciences, Tampere University, 33100 Tampere, Finland; tuuli.hirvilammi@tuni.fi

Received: 28 November 2019; Accepted: 30 December 2019; Published: 3 January 2020

check for updates

\begin{abstract}
Welfare states are highly dependent on the economic growth paradigm. Especially in social democratic welfare states, growth dependence has historically been accompanied by the notion of a virtuous circle, which ensures that social policy measures do not conflict with economic growth. However, this policy idea ignores the environmental impacts that are now challenging human wellbeing and welfare goals. In this conceptual research article, I reframe the virtuous circle of the welfare state by revealing its unintended consequences and internal contradictions before introducing a more sustainable policy idea. I argue that this new concept-a virtuous circle of sustainable welfare-could have transformative potential in designing a planned and socially sustainable degrowth transformation. Drawing on historical institutionalism, degrowth, social policy and sustainable welfare state research, I advocate for the virtuous circle as a heuristic tool to provide an appealing and convincing narrative for sustainable welfare state beyond growth. The policy idea of virtuous circle addresses interrelated institutional reforms and positive feedbacks between different institutions and policy goals. It also emphasizes that a holistic approach is necessary to avoid trade-offs and contradictions between social, environmental, and economic policies.
\end{abstract}

Keywords: virtuous circle; welfare state; social policy; policy idea; institutionalism; degrowth; transformation

\section{Introduction}

In growth-based welfare states, zero economic growth typically leads to negative consequences for wellbeing [1] (pp. 74-75). When investors lose their faith in investments and consumption demand declines, bankruptcies multiply, unemployment rises, and the demand for social benefits escalates. Decreased tax revenues mean that the state's public expenditure must be diminished, or the state will run into deficit. In an economy that is neither growing nor shrinking, the income of one population group can only increase at the expense of another, which would lead to distributional conflicts [2-4].

This kind of vicious circle following economic recessions is often upfront in policy debates in welfare states and can be argued to be one driver behind "growth-fetishism" [2] (p. 565). It is supported by people fearing wellbeing losses and policymakers worried about an erosion of political support. Fear of the vicious circle is logical in welfare states that have developed side by side with capitalist economic growth [1]. The growth dependence has historically been accompanied by the policy idea of a virtuous circle, the notion that social and economic policies are interrelated and that social policy measures do not conflict with economic growth. This idea has helped justify social policy measures and enabled the development of tax-funded comprehensive welfare states [5].

Recently, however, growth-driven "virtuous circles have ultimately proved to be somewhat perverse in more than one respect" [6] (p. 33). Economic growth as one driver of great acceleration has brought growing social inequality and ecological degradation on both the global and local levels [7-9]. While welfare states have achieved many positive wellbeing outcomes, they have also exceeded biophysical boundaries [10]. Due to overconsumption, ecosystems are deteriorating, and biodiversity 
is declining "faster than at any time in human history" [11] (p. 3), causing permanent risks to human well-being. Environmental impacts are closely connected to gross domestic product (GDP) growth e.g., $[12,13]$, which challenges the dominant growth-dependency of welfare states. What is needed to restore nature, according to the Intergovernmental Science-Policy Platform on Biodiversity and Ecosystem Services (IPBES), is a sustainable pathway that steers away from the current paradigm of economic growth [11] (p. 10).

This calls for degrowth, a transformation towards a society "in which growth and development are not central metrics or signifiers" [14] (p. 432), but in which the focus is on the redistribution of wealth and on the need to live within planetary boundaries. Degrowth would mean democratic and redistributive downscaling of economy and environmental impacts, especially in wealthy welfare states $[3,15]$. Since degrowth challenges the hegemonic idea of growth, it also challenges the foundations of growth-dependent welfare states. Consequently, it is crucial to revisit those foundations and to confront the prevalent imaginaries captured by the belief in the positive "upward spiral" [16] between economic growth and welfare institutions.

In this article, I argue that the transformation requires a new policy idea: the virtuous circle of sustainable welfare [17]. I draw on historical institutionalism that emphasizes the role of policy ideas in institutional changes e.g., $[18,19]$ to argue that this new concept could function as a roadmap and provide a convincing and appealing narrative of the welfare state beyond growth. I use the virtuous circle concept as a heuristic tool to provide a symbolic framework for the transformation and to frame it as something that could be convincing and appealing. Policy ideas are mental maps and normative frameworks that normally lie in the background of policymaking, but they play a pivotal role in providing guidelines and legitimacy for more concrete policy instruments or in constraining action by limiting the range of acceptable policy alternatives $[18,20]$. Policymakers also refer to policy ideas when they frame policy alternatives with the aim of increasing popular support and to "sell them to the public while constructing the need to reform" [21] (p. 6). To comprehend how the idea of the virtuous circle has, first, legitimated the priority of economic growth and, second, could be used in a new context, is therefore of vital importance.

This article aims to contribute to institutional changes and sustainable welfare research by exploring the transformational potential of the virtuous circle policy idea. I examine how this idea has justified extensive social policies and argue that a revised version of the same attractive policy idea can be valuable when seeking legitimacy and political support for sustainable welfare beyond growth. When envisioning policy changes, it is worth revisiting the original idea of the virtuous circle because of its power to produce positive effects and to connect different policy goals (see also [16]). I also suggest that reframing the original policy idea by revealing its unintended consequences and internal contradictions can pave the way for a more sustainable alternative.

This conceptual article combines research on social policy and welfare states, the theory of cumulative causation [22], and the virtuous circle concept with research on sustainable welfare and degrowth. In Sections 2 and 3, I discuss the historical roots of the policy idea of the virtuous circle and the role it has played during the expansion of the welfare state and in more recent discussions on social investments and on the "Economy of Well-Being" [23]. In Section 4, I elaborate on the need to reframe the traditional virtuous circle policy idea from an ecological perspective. In Section 5, I describe the new policy idea of the virtuous circle of sustainable welfare and explain in greater depth why the concept is worth being developed further. What kind of policy idea could overcome the fears of vicious circles and make the transformation more convincing and appealing?

\section{The Virtuous Circle: A Policy Idea of Positive Feedback and Self-Reinforcement}

The elements of mutual benefits among equality, welfare states, and economic growth were already visible in policy discourses in the 1930s, when social policies had to be justified in relation to a longstanding liberal tradition that fiercely resisted state interventions. According to Kettunen [5] (p. 28), the idea of the virtuous circle changed the political discourse in that decade due to its ability to 
expand the focus from narrow economic interests to systemic integration. The International Labor Organization (ILO) played a significant role in promoting a society "in which the objectives of social equality and security on the one hand and of economic efficiency, competitiveness, and growth on the other were supposed to reinforce each other" [5] (p. 27).

Since the 1950s, the virtuous circle concept has been supported by the theory of circular cumulative causation (CCC) developed by Gunnar Myrdal [24]. CCC theory treats the elements of social and economic processes as highly interrelated, so that the deterioration of one element necessarily influences other elements [22]. Producing knowledge of the interlinkages across policy measures, co-benefits, and potential trade-offs, CCC and virtuous circle analysis resemble systems thinking [25-27].

Myrdal developed CCC theory as a critique of stable equilibrium and the stability that is generally assumed in neo-classical economics. When defining economic and structural changes, Myrdal [22] (p. 13) argued that there is no tendency that would automatically stabilize the social system; rather, the contrary is true. If a change occurs, it accelerates supporting changes rather than countervailing changes, which moves the whole system in the same direction as the first change, only much faster. According to Myrdal, this social process of circular causation "tends to become cumulative and often to gather speed at an accelerating rate" [22] (p. 13). Myrdal thus paid attention to cumulative causes, causal chains, and path dependencies that have since been discussed in the context of historical institutionalism [20].

According to Myrdal, social change emerges in a process of reciprocal interaction between different elements in society. In both the vicious and virtuous circles, all factors are interrelated. A cumulative process of mutual interaction is a change in which "the change in one factor would continuously be supported by the reaction of the other factor and so on in a circular way" [22] (p. 16). When studying this dynamic process, Myrdal began to see that social problems are related to complex interlocking changes.

Like Keynesian macroeconomics, Myrdal emphasized the role of the state in regulating the market economy towards full employment. Myrdal [22] also argued that economic processes are always part of social processes and, therefore, that economic planning ought to consider diverse categories of the social system like conditions of production, levels of living, and attitudes and policies. He also made clear that this approach includes value premises that can only justify the desirable and possible features of the system. Myrdal favored the values of democratic equality, as was clear in his concern about the vicious circle of increasing international inequalities. For him, CCC was a conceptual tool to break the vicious circle of poverty that was caused by economic, social, and political inequalities acting on their own and upon one another [26].

During the interwar period and after the Second World War, such ideas of positive cumulative effects between economic and social realms were successfully framed as a virtuous circle of the welfare state. The frame of the attractive combination of equality, efficiency, and solidarity changed the political discourse in favor of welfare institutions, especially in Nordic social democratic welfare states [5] (pp. 28-30). Policy compromises were built on the assumption that economic growth, employment, and social policy were mutually reinforcing. Expansive social policies and increases in social expenditures became legitimate when political forces found compromises between the interests of employees and capitalists. It was this economic reasoning that made the wealthy population support expansion of the welfare state and the redistribution of income, whereas the working class began to favor economic growth due to its clear connection to the overall good and its benefits for society [28]. The "historic compromise" involved social democratic governments' ensuring that full employment and progressive taxation would reduce economic inequality and support public services at the same time as capital remained intact and capitalist economic growth was encouraged [28] (pp. 124-129).

In line with Myrdal's writings, the notion of the virtuous circle was closely connected to values and ethical norms. The trust in a "virtuous circle between economy, politics and ethics" was particularly important in Nordic countries, where it gained an ideological status in politics by managing to combine "the spirit of capitalism", "the utopia of socialism", and "the idealized tradition of independent 
farmer" [29] (pp. 158-159). This shows how the virtuous circle notion was based on both economic theory and ideological beliefs, which supported its role as a powerful policy idea.

When looking more closely at historical developments in Finland, we can see how the promises of the virtuous circle was used to design social reforms. In his book Social Policy for the Sixties: A Plan for Finland, social policy researcher Pekka Kuusi [30] vigorously promoted the idea of positive self-reinforcement by eloquently describing how social policy would support economic growth. Kuusi addressed the commonly held critique of public spending and the "traditional view" by which social policies were seen as impairing economic growth [30] (p. 72). Following the ideas of Myrdal [22] and Keynes [31], Kuusi conceived how democracy, social equality, and economic growth were interdependent in a fortunate way: "Myrdal's theory of cumulative growth leads to an entirely new view of the function of social policy in modern society" [30] (p. 74). His book has played an important role in the development of the Finnish welfare state [32] because it managed to justify the central role of economic growth: to avoid the vicious circle of poverty, the good of the citizen was strongly associated with increasing the national income, which itself was proposed as "a unifying, general goal of public policies" [30] (p. 48). When the "growth-oriented society" [30] (p. 94) was fuelled by the public's hopes for continuous improvements in their own and their children's well-being, economic growth became a necessity.

Drawing on the Keynesian theory of aggregate demand, Kuusi saw social policy as an important institution for increasing consumption. Social policies were justified by arguing how redistribution of income could increase both productivity and consumption, given the knowledge that the "propensity to consume" is higher among low-income households [31] (p. 120). Social benefits for low-income households could thus safeguard and boost purchasing power and consequently increase "the aggregate consumption of the total population" [30] (p. 85). From this perspective, social policy became a servant of the economy: one of its explicit purposes was to support economic growth by mobilizing human resources and stabilizing economic activity [30] (p. 86). Accordingly, welfare states became integral parts of growth constellations that introduced mass production and consumption and increased the use of fossil fuels and natural resources [33] (p. 52).

\section{The Virtuous Circle and Its Challengers}

Ideas provide not only roadmaps but also symbols and "discursive schema that actors can use to make these maps appealing, convincing, and legitimate" [34] (p. 381). I argue that the virtuous circle of mutually beneficial social and economic goals has been just such a policy idea: a symbol that considers the welfare state an appealing and legitimate political project. The virtuous circle was an attractive policy notion that policymakers could use to legitimate the coercive power the state used to increase interventions like redistribution and regulating the market economy. Consequently, social policies were built on the expectations that capitalist accumulation would increase the public spending needed for wider redistribution and social benefits.

Figure 1 illustrates the key elements of the traditional idea of the virtuous circle and highlights the assumed interconnections between various policy goals and institutions. In the circle, GDP growth is the dynamo: it sets the circle in motion, causing favorable social development that then reflects positively back onto economic growth. Since the welfare state rests upon full employment and income generated in the market sector, the precondition for a welfare state and therefore the necessary policy goal is an increase in economic prosperity [30]. GDP growth requires and generates mass production and consumption, with a focus on exchange values rather than use values. This is reinforced by a wage-earning culture and full employment. The highest possible employment rate is an important policy goal because it also influences the demand for public spending and the amount of tax revenues. When households gain income they need through employment, investments, and rent seeking, the need for social benefits remains small, especially for benefits targeted to the working-age population (e.g., unemployment insurance and means-tested minimum incomes). Due to the improved tax revenues, the state can invest adequately in public services and social benefits. [35] Even though taxation on 
income and wealth reduces the gross income of certain households, its overall impact on consumption and growth remains positive. While the improved purchasing power of low-income households increases consumer demand, the economy — as measured by GDP—grows. Redistribution also reduces inequality [16]. The virtuous circle leads to greater wellbeing (in terms of higher standards of living) and a more equal society, which in turn benefits the economy through the stability and profits generated through production and consumption [30].

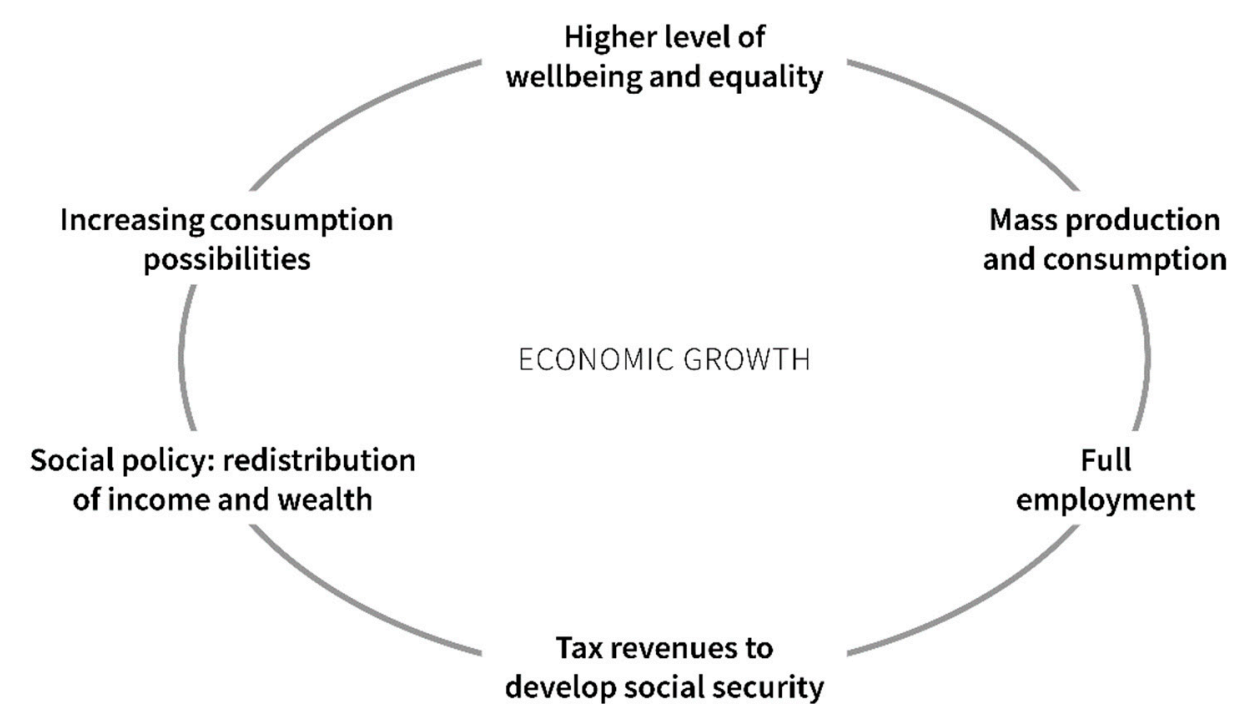

Figure 1. The virtuous circle of welfare states.

This is roughly how the traditional virtuous circle of the welfare state has operated in the mechanisms of the real economy, particularly during its 'golden age': the three decades from the end of World War II through the end of the 1970s [36]. The growth of the national economic pie made it possible for everyone to receive something.

Since the end of the 1970s, the policy idea of the virtuous circle has been challenged by a paradigm shift in macroeconomics. When the Keynesian policy paradigm of economic regulation seeking full employment was replaced by a monetarist paradigm, public spending was framed as unacceptably high and harmful for economic growth [37]. This questioned the legitimacy of social policies that extended beyond the bare minimum. Instead of positive self-reinforcement, economic growth was argued to be in danger due to social spending and bloated welfare states. The new macroeconomic paradigm was successful when it managed to provide an appealing narrative for politically influential interest groups, demonstrating once again how ideas interact with interests and institutions [36,37].

Even though the neo-liberal paradigm challenged the idea of the virtuous circle and mutual benefits, it did not destabilize the growth dependency of welfare states; in fact, the reverse was true. Economic growth and private-sector profits are still regarded as important preconditions for public spending: state budgets in welfare states are highly dependent on money generated by commercial banks and tax revenues paid by private companies. At the same time, concerns about growing public debts and deficits became prevalent among policymakers. The dependency on growth is also present when policymakers justify growth policies that prioritize economic growth and business opportunities as solutions to social and environmental problems. The political mantra seems to be: "Without growth, no sustainability, but for the sake of growth, no sustainability policy" [2] (p. 562). In addition, the neo-liberal critique of the virtuous circle focused only on the relationship between economy and social policy, leaving the environmental impacts of economic growth unexamined and thus untouched.

Recently, ideas supporting social investments and virtuous circles have gained renewed prominence in public policy discourse. The advocates of the "social investment state" and various "Third Way" policies have supported and justified social policies by arguing that social investments do not 
hinder economic growth and will in fact be profitable in the longer run [28] (pp. 235-237). The concept of the virtuous circle is used in the Organisation for Economic Co-operation and Development (OECD) background paper for the EU Council conclusion on the "Economy of Well-Being" (adopted on 24 October 2019). This approach "seeks to establish and sustain a 'virtuous circle' in which both elements-sustainable economic growth and wellbeing — work together to the benefit of people and society" [23] (p. 4). The order of importance and the aim of social investments are clearly stated: "By paying attention to the sustainability of wellbeing over time, policy-makers can maximize the potential for long-term economic growth and better protect their economies from adverse shocks" [23] (p. 4). Unfortunately, the virtuous circle in this context also neglects biophysical limits. Environmental sustainability is mentioned only once and the concept of "sustainable economic growth" is phrased in a way that refers to maintaining current levels of growth rather than making it truly sustainable in terms of material use or carbon emissions.

\section{Reframing the Virtuous Circle from the Ecological Perspective}

Amidst global inequality and ecological crises, it is questionable whether the virtuous circle of the welfare states is in fact virtuous. Next, I focus on the unsustainable underpinnings and internal contradictions of the virtuous circle with the intention of reframing the policy idea. Drawing on historical institutionalism, I argue that reframing can be a source of political change if it reveals the contradictions that undermine institutional reproduction $[20,21]$. The fixation with economic growth is a contradiction that degrowth research has discussed from the perspective of justice [38], alternative economic spaces [39], or wellbeing [1], for example. Next, I focus on the ecological perspective. I identify three caveats of the policy idea and illustrate how the traditional virtuous circle is actually embedded in a vicious circle of ecological collapse.

The first caveat concerns the policy goal of economic growth as such. As degrowth research illustrates, the belief in cumulative economic growth as beneficial for human wellbeing has proved to be outdated. Since the 1970s, ecological economists have warned that our environmental resource base is unable to support unlimited growth and that continued economic growth could cause irreversible damage due to the cumulative impacts of different pollutants [40]. This damage, cumulative changes and vicious circles of climate change and ecological collapse are clearly evident in recent research on planetary boundaries, material use, emissions, and biodiversity [7,11,12,41,42]. Decarbonization and dematerialization can become possible in well-designed policy settings [43]. However, even though an absolute decoupling of GDP from emissions has been possible in some regions, "it is unlikely to happen fast enough to respect the carbon budgets for 1.5 and 2 degrees against a background of continued economic growth" [12] (p. 12). Ongoing research provides a scientific knowledge base of concrete boundaries, sustainability targets, and sufficient levels for material use and emissions, thus denying policymakers any excuse to ignore the vicious circle or claim that there is not enough information on its sustainable alternative.

Second, the policy idea of the virtuous circle contains an unsustainable priority order between economic and social goals. As the historical analysis above shows, social goals including human wellbeing and equality became (at least implicitly) suppressed by GDP growth. What was supposed to be a means for wellbeing became an end in itself. Wellbeing seems to be "an interesting side-note" [23] (p. 7) that is largely separated from the natural environment. This view is challenged by research on social-ecological systems and ecological economics, where the economy is seen as a subsystem of society. The economy should be harnessed to enhance human wellbeing within planetary boundaries [8]. Accordingly, welfare institutions should be embedded in the ecological context, and economic policies should be subordinate to social goals.

The third major caveat of the policy idea of the virtuous circle is its historical ignorance of the ecological context, as if the circle were floating in the air without energy from fossil fuels or the other natural resources provided by the planet. The policy idea of a virtuous circle established a compromise between social and financial goals without paying attention to the negative environmental 
consequences of economic growth. This internal contradiction is illustrated in Figure 2, in which the virtuous circle is connected to negative environmental impacts.

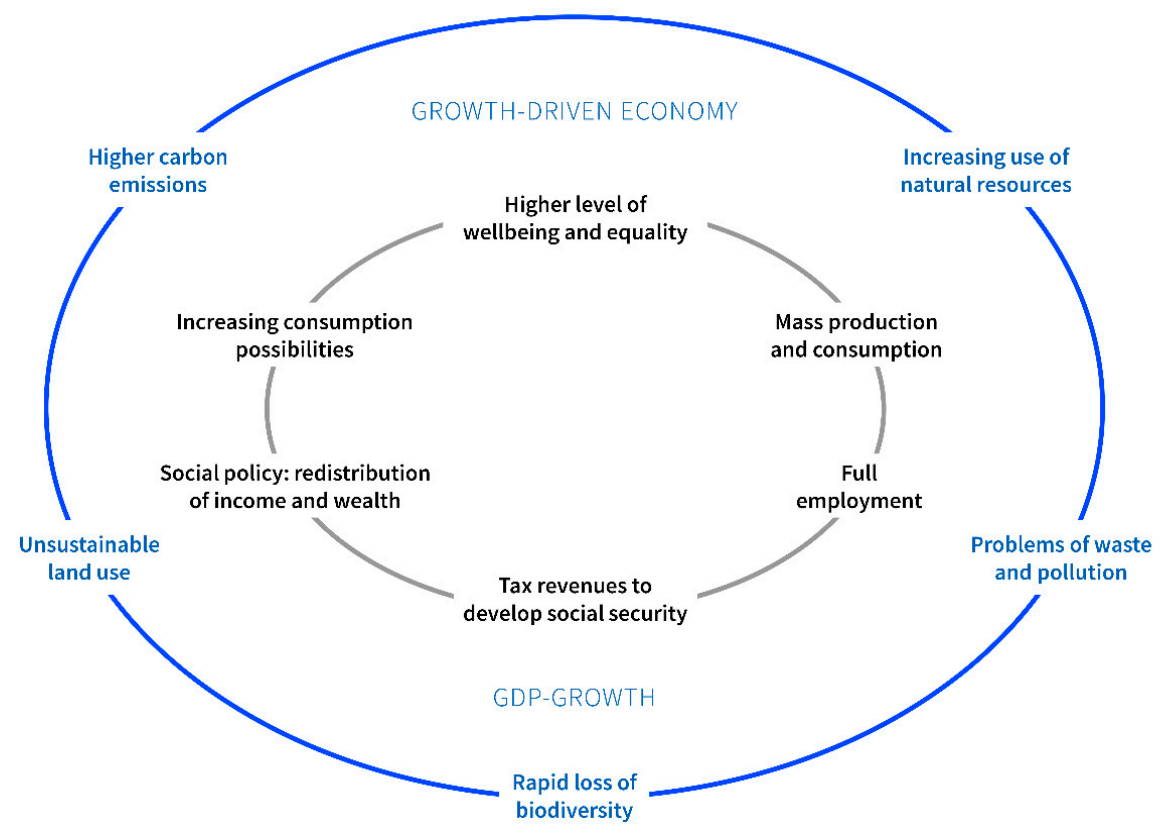

Figure 2. The virtuous circle of welfare states embedded within the vicious circle of ecological collapse.

While maintaining "virtuous" human development, welfare states are strongly embedded in the vicious circle of ecological collapse and climate change. Mutually beneficial social and economic policies are reinforcing systemic changes in ecosystems. For both circles, economic growth is a mediating driver causing positive feedbacks but somehow in reverse order: it works in the direction that has been beneficial for welfare systems and in the direction that harms ecosystems.

Consequently, welfare states need to deal with the new and more existential "configurations of risk, injury, and inequity" caused by climate change and declining biodiversity [44] (p. 113). The increasing use of natural resources generates more and more waste, let alone carbon emissions. Overconsumption, climate change, exploitative land use, and pollution are all contributing to dramatic losses in biodiversity [11], which are already endangering the preconditions for human wellbeing. The ostensibly virtuous circle is bounded within a trajectory that is leading us to "Hothouse Earth", to conditions that would be inhospitable not just to current human societies but also to many other species [45] (p. 8253).

I argue that reframing the policy idea of the virtuous circle is necessary to overcome a current paradox: economic growth is causing risks to human wellbeing, and yet all welfare systems depend on the growth paradigm. This internal contradiction demands a rethinking of the actual connections between different elements of positive feedbacks and cumulative changes. Policy ideas are feasible only as long as they can provide a convincing roadmap for the future [18]. This is not the case with the traditional policy idea of the virtuous circle because it does not provide a solid narrative of how to enable long-term human wellbeing. In the end, welfare states have not succeeded in their goals of providing safety and improving wellbeing.

According to Pierson [20] (p. 134), reframing a policy idea by identifying the mechanisms that generate constraints in policies can reveal powerful insights into institutional change. Therefore, a reframed virtuous circle could induce a way out of the locked-in situation in which the goal of sustainable welfare is, on the one hand, widely acknowledged and policy alternatives exist, but, on the other, political courage and the capability for transformation are weak.Many policymakers are already highly aware of the limits to growth and advocate for sustainable development goals. Despite the growing interest in sustainability and the degrowth discussion, it seems that the only policy 
alternatives deemed laudable are those in line with the growth paradigm [46,47], apparently because of the underlying belief that a growing GDP is necessary to generate funding for welfare institutions such as education, healthcare, and universal social security, along with other public goods. This shows in a practical way how, in addition to institutional lock-ins, policy ideas can also constrain "solutions that policy makers perceive as instrumentally useful" [34] (p. 392). Responsible policymakers cannot afford to take risks that could violate basic services as long as a convincing policy idea to build a sustainable virtuous circle remains lacking.

\section{Towards the Virtuous Circle of Sustainable Welfare}

Next, I elaborate the virtuous circle policy idea in the context of sustainable welfare beyond growth. How can this idea be further developed and updated? Historically, the idea of the virtuous circle has been used to refer to both existing relationships and to anticipate the normative standards of society for future change and potential reforms [5]. The use of the virtuous circle concept in this article is an act of "conversion" in which I provide an existing historical layer of institutions with new meanings (see [48] (p. 7)).

Even though Myrdal's original idea was strongly linked with capitalist accumulation and a growing state economy, I argue that the virtuous circle concept can be redefined and reframed in the context of postgrowth welfare states. The basic idea of systemic, cumulative change and reinforcing or balancing feedbacks between different institutions and policies is valid and can even be applied in a steady state economy. I see two significant reasons for and advantages of building on the original policy idea. First, the virtuous circle concept emphasizes mutual benefits and favorable development, giving it the potential to reassure policymakers, stakeholders, and the general public of the positive impacts of transformation. Consequently, it can make necessary policy changes more attractive. With a positive metaphor, policymakers can frame policies so that they are more acceptable for voters [18] (p. 26).

Second, the virtuous circle idea changes the focus from individual policies to the interconnections between different policy goals. It enables the move "from linear mechanics to complex dynamics" [8] (p. 112). When elaborating CCC, Myrdal [22] (p. 14) wrote how "the essence of a social problem is that it concerns a complex of interlocking, circular, and cumulative changes". This also holds with ecological problems like climate change, which is unquestionably a highly complex policy problem [44].

As a dynamic policy idea, the virtuous circle has the potential to illustrate policy changes and to address path dependencies, interlocks, and the complex webs of taxation policies, employment policies, and social benefits that need to be redesigned and rebuilt to mitigate climate change and reduce natural resource use while safeguarding well-being. The focus on cumulative chain processes reminds us that if an improvement is achieved, for example, in the unemployment sector or in environmental taxation, it will eventually have an impact on other policy sectors as well. The same applies when developing new policies.

Therefore, the virtuous circle is an integrative policy idea in line with the quest for integrated ecosocial policies (see [44]). It can encompass the interrelation between the three goals of sustainable welfare summarized in "wellbeing and social justice within planetary boundaries" [44] (p. 37) and has the potential to overcome political conflicts and build synergies. It provides a broader frame for various policy alternatives that have previously been developed in different research fields without clear connections with one another [1]. The list of suggested policy alternatives for welfare state reform is already abundant in degrowth research and in research discussions on sustainable welfare e.g., [1,3,44,49-51] but a shared narrative is missing. New policy ideas can pave the way for implementing new policy alternatives due to the dialogical nature of policy ideas and measures [21] (p. 9). On the one hand, the development of policy alternatives has the ability to support the more general policy idea of the virtuous circle by showing that alternatives do exist and that cumulative change can occur when establishing more sustainable policy instruments. On the other hand, policy alternatives can become more feasible when they are framed within the virtuous circle. 
The policy idea that supports sustainable welfare beyond growth should provide a convincing and appealing narrative that explains how to satisfy human needs within ecological limits and to provide means to finance welfare institutions. To overcome the fears of wellbeing losses, the new idea of the virtuous circle of sustainable welfare ought to simultaneously tackle the fiscal crisis, the climate crisis, and rising social inequality. All welfare states have traditionally shared three broad goals: redistribution, social consumption, and social investment [44]. These goals have no reason to cease during the transformation towards a sustainable welfare state beyond growth. The new welfare system will be redistributive and should not violate the social and economic rights for a decent income and social services that are guaranteed by legislation in developed welfare states.

Whereas the traditional virtuous circle emphasized the role of satisfying material needs and increasing the standard of living, the sustainable policy idea could build on needs theories that consider needs as plural and non-substitutable e.g., [44,52]. People should be able to meet their needs and flourish in all dimensions of well-being: Having (basic sustenance), Doing (meaningful activities), Loving (connective and compassionate relations), and Being (self-actualization and a sense of presence) [49,52]. If a sustainable welfare state managed to support multidimensional wellbeing and produce more equal outcomes, the demand for state-funded benefits and services could even decrease. In the end, the virtuous circle has the potential to prevent poverty- and growth-related social and health problems like unemployment, stress, and (climate) anxiety.

What might this new policy idea of a virtuous circle of sustainable welfare look like? What are the elements that could replace the growth-driven virtuous circle and its embeddedness within the vicious circle of ecological collapse? How do we bring about cumulative changes that lead towards sustainable welfare? Figure 3 shows a tentative illustration of two virtuous circles with reinforcing and balancing feedbacks. The new policy idea of sustainable welfare sees the two circles as interconnected. The inner circle of a sustainable welfare system could be in accordance with sustainable ecosystem processes if growth-oriented ideas and practices are replaced with the goals of sustainable wellbeing, equality, sufficiency, shared work, and social security. The level of resource use associated with meeting needs can be dramatically reduced by better identifying what is enough. Sufficiency can be endorsed by differentiating necessities from luxuries and by defining "consumption corridors" between minimum standards that allow a decent living for all and maximum standards in accordance with biophysical boundaries [53].

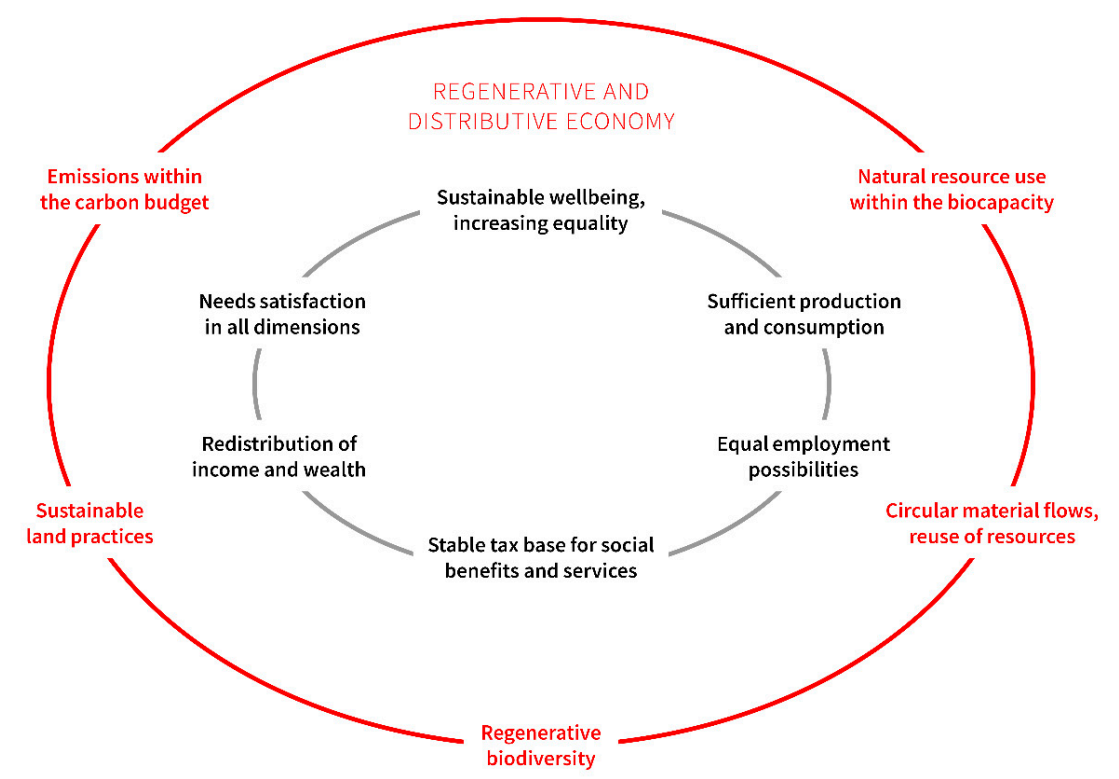

Figure 3. Two virtuous circles with reinforcing and balancing feedbacks. 
In this article, I describe the policy idea of the virtuous circle of sustainable welfare with the following narrative of cumulative changes and feedbacks. When production and consumption are both based on sufficiency, households can be assured of all necessities while natural resources are used only at the level that the biocapacity can generate, or around 7 tonnes per capita per year [10]. Sustainable investments as well as limited production and consumption levels enable emissions reductions in accordance with the global carbon budget [42]. The demand for materials and amount of waste generated are reduced when production and consumption follow cradle-to-cradle thinking in a circular economy in which both biological and technical nutrients are used many times through cycles of reuse and renewal [8]. Human impacts on the earth remain within planetary boundaries, which is beneficial for the policy goal of sustainable well-being. Despite lower levels of production and consumption, a regenerative and distributive economy [8] will provide jobs and a decent standard of living. It opens employment possibilities not only in the conventional employment market that are based on narrow, economically valuable notions of employment, but also in the community economies [54] and caring economies [55] that could flourish when indicators other than GDP are used to measure success. Welfare institutions can function without GDP growth when the tax base is relatively predictable and stable. Sustainable public and private investments and sufficiency-based consumption generate adequate tax revenues that the state and municipalities can use to fund social services and benefits, including benefits for pensioners. Redistribution of income and wealth increases equality but also has the potential to diminish pressures on biodiversity and land use since more equal communities can reduce consumption demand by lowering the need for-and payoffs from-status consumption [56]. Redistribution is also legitimized because the largest incomes are found to be harmful incentives for the environment. A welfare state embedded in a regenerative and distributive economy can, as a consequence, ensure sustainable wellbeing for all while limiting environmental impacts to a sustainable level.

This is how the virtuous circle could operate during the transformation towards a sustainable welfare state beyond growth. The aim of the policy idea is that its associated changes will lead to win-win situations in which social and ecological problems are simultaneously addressed. It can thus attain the policy goals suggested in the degrowth literature: reduction of environmental impact, redistribution of income and wealth, and a "transition from a materialistic to a convivial and participatory society" [51] (p. 330). This requires governance and regulation of reinforcing and balancing feedbacks between a variety of institutional changes; it requires state interventions.

The traditional virtuous circle of the welfare state advocated for and legitimized a strong state and more state interventions than the liberal tradition and neo-classical economics could have anticipated. I draw on this history and see-joining Gough [44] (p. 145)—that the policy idea of a virtuous circle of sustainable welfare favors "an active interventionist 'innovative' state, with substantial public investment and greater regulation and planning". The "green state" plays a pivotal role in decarbonizing economy [57] and facilitating the degrowth transformation [15,51]. As Koch has shown, state-led ecosocial policies can overcome the imperative of economic growth if they are "integrated into comprehensive strategy" [46] (p. 13). Currently, a system boundary that Hausknost [47] calls a "glass ceiling of transformation" curtails the prospects of transformation towards a sustainable welfare state. Those states that do try to introduce sustainable policies tend to hit this glass ceiling; only policies that do not limit economic growth and endanger citizens' wellbeing are feasible [47] (p. 14).

To break the glass ceiling, the new virtuous circle of sustainable welfare states should contain a more ambivalent stand on GDP growth. Whilst the attitude towards growth has been very positive in welfare states, the new policy idea of a virtuous circle would approach growth more openly: it is not just positive, negative, or neutral, but might be all three on different occasions $[4,8,9]$. The political priority should be on ecological sustainability and increasing social equality rather than on economic growth. The regenerative economy, thus, becomes a mean, an intermediating driver between social and environmental goals. 
Sustainable welfare states necessarily require a new political economy and macroeconomic management e.g., $[8,46]$. Traditionally, the policy idea of the virtuous circle was supported by the Keynesian policy paradigm and challenged by the neo-liberal policy paradigm with roots in monetarism and neo-classical economic theories. Both were extensively focused on economic growth, whereas the policy idea of a sustainable virtuous circle seeks to escape the growth paradigm. What economic theories could best inform this escape and accompanied this policy idea? A lively research discussion on heterodox economics is already benefiting the development of the policy idea. Ecological and post-Keynesian economics, caring economics [55], doughnut economics [8], Marxist approach to degrowth macroeconomics and research on community economies [54] all share some features that are related to the aforementioned elements of the sustainable virtuous circle.

Though the development of a macroeconomic policy paradigm is beyond the scope of this article, I refer briefly to the research debate on the relationship between post-Keynesian macroeconomics and ecological economics [58,59] due to the historical link between the Keynesian paradigm and the virtuous circle. It appears that ecological economics has been powerful in emphasizing the biophysical boundaries of economic activities but weak in dealing with macroeconomic issues. Post-Keynesians, by contrast, have focused on understanding the role of money and financial markets, unemployment, inflation, and effective demand without paying any attention to ecological context or to limits on growth [43].

However, there are interesting commonalities between the two theories that could benefit the policy idea of a new virtuous circle. They both share a focus on timing and the historical paths of economies. They also emphasize the elements of uncertainty, value political economy, and acknowledge the significance of institutions in determining economic outcomes. Both approaches focus on complex systems and share the same doubts that market forces can lead to a determined equilibrium (as Myrdal did when developing CCC). They are interested in path dependency and irreversibility. A post-Keynesian approach can provide a means to analyze socio-ecological regimes and the relationship between environmental changes and economic institutions. Both agree that markets require active political guidance to avoid economic or ecological crisis and advocate regulation of various feedbacks, such as those between employment levels, interest rates, and material flows $[53,56]$. Post-Keynesians also argue for the significance of state-funded investments that are necessary for the rapid transition towards fossil-free welfare states. A post-Keynesian approach could help alleviate the fears of a public deficit that are currently strong constraints on social spending and any sustainable investments $[59,60]$. However, an increase in monetary supply through Green New Deal programs caries the risk of increasing aggregate consumption demand and thus, unwelcome environmental impacts. Further research is therefore needed to explore whether it is possible to build a truly ecological post-Keynesian policy paradigm that could support the policy idea of the virtuous circle of sustainable welfare.

\section{Discussion and Conclusions}

"The difficulty lies, not in the new ideas, but in escaping from the old ones, which ramify, for those brought up as most of us have been, into every corner of our minds". [31] (p. viii)

In this article, I have argued that the new policy idea of a virtuous circle of sustainable welfare could have the transformative potential to design a planned and socially sustainable degrowth transformation. I have placed the traditional idea of the virtuous circle to the new context of sustainable welfare beyond growth. As the virtuous circle has legitimized the transformation during the welfare state expansion, it can be used as a symbolic frame that provides a convincing narrative towards a sustainable welfare state. Contrary to the contemporary welfare discussion, in which GDP growth is seen as a precondition for wellbeing and therefore a goal in its own right, the virtuous circle of sustainable welfare is founded on ecological sustainability as the primary precondition for all policies. This builds the legitimacy of sustainable welfare and opens up the political space for ecosocial policy measures that are geared to meet both social and environmental goals. The concept of virtuous circle emphasizes that a holistic 
approach is necessary to avoid trade-offs and contradictions between social, environmental, and economic policies.

I suggest that the virtuous circle can be used both in policy processes and in sustainable welfare research. For policy makers, it provides an appealing frame to promote interrelated institutional reforms and positive cumulative changes between different institutional changes and policy proposals. Currently, political support for welfare systems and the fear of wellbeing losses seem to hinder policy changes. As long as welfare state funding is not decoupled from a growth paradigm, rapid decarbonization might remain merely a distant goal. The pressing question is how to maintain equal and democratic societies when transitioning to welfare states beyond growth. To overcome the fears of vicious circles and wellbeing losses, the transformative idea of the virtuous circle of sustainable welfare is proposed to break the political and ideological status quo and broaden the political imaginaries see [15] (p. 379).

For sustainable welfare researchers, the virtuous circle policy idea can provide a heuristic, unifying framework to understand systemic changes and envision coherent transformation strategies. For example, it could be used as a dynamic framework for structural equation modeling of different policies and outcomes or simulation scenarios of various policy mixes (see e.g., [16,59]) when studying how various policy measures of basic and maximum income, work time reduction, and monetary reforms are linked to the virtuous circle policy idea. Future research agendas could also include case studies from various countries to further scrutinize the usefulness of the policy idea of virtuous circles. It is also unknown what kind of actors and epistemic communities could effectively disseminate the policy idea to policy arenas or what kind of institutional filters should be broken down to adopt new policies.

To become legitimate and transformative, policy ideas do need the support of powerful actors and interest groups. What are the possibilities for various interest groups to break policy silos and implement new policy ideas? Which actors could carry the policy idea of the sustainable virtuous circle into policy debates? Researchers can enable potential actors going forward by showing them how the renewed virtuous circle speaks to their concerns.

Funding: This research was supported by The Strategic Research Council (SRC) at the Academy of Finland research project “Towards EcoWelfare State: Orchestrating for Systemic Impact (ORSI)” (327161).

Acknowledgments: I would like to extend thanks to Jussi Ahokas, Tuula Helne, Max Koch, Katherine Trebeck, and Kristoffer Wilén, as well as to members of OMAgroup at Tampere University who have commented on my ideas and earlier versions of the paper.

Conflicts of Interest: The author declares no conflict of interest.

\section{References and Notes}

1. Büchs, M.; Koch, M. Postgrowth and Wellbeing: Challenges to Sustainable Welfare, 1st ed.; Palgrave: Cham, Switzerland, 2017.

2. Spangenberg, J.H. The growth discourse, growth policy and sustainable development: Two thought experiments. J. Clean. Prod. 2010, 18, 561-566. [CrossRef]

3. Kallis, G.; Kerschner, C.; Martinez-Alier, J. The economics of degrowth. Ecol. Econom. 2012, 84, $172-180$. [CrossRef]

4. Antal, M. Green goals and full employment: Are they compatible? Ecol. Econom. 2014, 107, $276-286$. [CrossRef]

5. Kettunen, P. The transnational construction of national challenges: The ambiguous Nordic model of welfare and competitiveness. In Beyond Welfare State Models: Transnational Historical Perspectives on Social Policy, 1st ed.; Kettunen, P., Petersen, K., Eds.; Edward Elgar: Cheltenham, UK, 2011; pp. 16-40.

6. Latouche, S. Farewell to Growth, 1st ed.; Polity Press: Cambridge, UK, 2009.

7. Steffen, W.; Richardson, K.; Rockström, J.; Cornell, S.E.; Fetzer, I.; Bennett, E.M.; Biggs, R.; Carpenter, S.R.; De Vries, W.; De Wit, C.A.; et al. Planetary boundaries: Guiding human development on a changing planet. Science 2015, 347, 1259855. [CrossRef] 
8. Raworth, K. Doughnut Economics: Seven Ways to Think Like a 21st-Century Economist, 1st ed.; Chelsea Green: White River Junction, VT, USA, 2017.

9. Trebeck, K.; Williams, J. The Economics of Arrival: Ideas for a Grown-Up Economy, 1st ed.; Policy Press: Bristol, UK, 2019.

10. O'Neill, D.W.; Fanning, A.L.; Lamb, W.F.; Steinberger, J.K. A good life for all within planetary boundaries. Nat. Sustain. 2018, 1, 88-95. [CrossRef]

11. Díaz, S.; Settele, J.; Brondízio, E.; Ngo, H.; Guèze, M.; Agard, J.; Arneth, A.; Balvanera, P.; Brauman, K.; Butchart, S.; et al. Summary for Policymakers of the Global Assessment Report on Biodiversity and Ecosystem Services of the Intergovernmental Science-Policy Platform on Biodiversity and Ecosystem Services; IPBES: Bonn, Germany, 2019.

12. Hickel, J.; Kallis, G. Is green growth possible? New Polit. Econ. 2019, 1-18. [CrossRef]

13. Fritz, M.; Koch, M. Economic development and prosperity patterns around the world: Structural challenges for a global steady-state economy. Glob. Environ. Chang. 2016, 38, 41-48. [CrossRef]

14. Demaria, F.; Kallis, G.; Bakker, K. Geographies of degrowth: Nowtopias, resurgences and the decolonization of imaginaries and places. Environ. Plan. E Nat. Space 2019, 2, 431-450. [CrossRef]

15. Asara, V.; Otero, I.; Demaria, F.; Corbera, E. Socially sustainable degrowth as a social-ecological transformation: Repoliticizing sustainability. Sustain. Sci. 2015, 10, 375-384. [CrossRef]

16. Hagfors, R.; Kajanoja, J. Welfare States and Social Sustainability-An Application of SEM and SOM in a Virtuous Circle Environment; Online Working Papers 15/2010; Kela: Helsinki, Finland, 2010.

17. The original idea of revisiting the concept of virtuous circle was first published in the Finnish article "Ympäristösosiaalipolitiikan lähtökohtia" [The premises of environmental social policy] (Hirvilammi \& Massa 2009) and further elaborated in another Finnish article, "Se pyörii sittenkin!—Kohti ekologisesti ja sosiaalisesti kestävää hyvinvoinnin kehää" [It is rotating!- -Towards ecologically and sustainable virtuous circle of wellbeing] (Laatu, Helne, \& Hirvilammi 2011). It was also briefly mentioned in the book Talous kasvun jälkeen [Economy after growth] (Joutsenvirta, Hirvilammi, Ulvila, \& Wilen 2016). I owe thanks to all my co-authors and acknowledge their support in further developing the idea.

18. Campbell, J.L. Ideas, politics, and public policy. Annu. Rev. Sociol. 2002, 28, 21-38. [CrossRef]

19. Lynch, J.; Rhodes, M. Historical institutionalism and the welfare state. In The Oxford Handbook of Historical Institutionalism; Oxford Handbooks Online; Fioretos, O., Falleti, T., Sheingate, A., Eds.; Oxford University Press: Oxford, UK, 2016. [CrossRef]

20. Pierson, P. Politics in Time: History, Institutions, and Social Analysis, 1st ed.; Princeton University Press: Princeton, NJ, USA, 2004.

21. Béland, D. Ideas and social policy: An institutionalist perspective. Soc. Policy Adm. 2005, 39, 1-18. [CrossRef]

22. Myrdal, G. Economic Theory and Under-Developed Regions; Gerald Duckworth \& Co.: London, UK, 1957.

23. OECD. The Economy of Well-Being. Creating Opportunities for People's Wellbeing and Economic Growth. OECD Background Paper for EU Delegations. 2019. Available online: https://data.consilium.europa.eu/doc/ document/ST-10414-2019-ADD-1/en/pdf (accessed on 8 November 2019).

24. Swedish economist and social policy researcher Gunnar Myrdal was very influential in designing the "folkhem", or Swedish welfare state, with his wife Alva Myrdal from the 1930s through the 1960s. I am aware that they also advocated questionable social engineering and population control policies. In this article, however, I rely only on Myrdal's CCC theory and the idea of the virtuous circle [22].

25. Fujita, N. Myrdal's Theory of Cumulative Causation. Evol. Inst. Econ. Rev. 2007, 3, 275-283. [CrossRef]

26. Berger, S. Circular cumulative causation (CCC) a la Myrdal and Kapp-Political institutionalism for minimizing social costs. J. Econ. Issues 2008, 42, 357-365. [CrossRef]

27. CCC also resembles the "circular flow diagram" that economist Paul Samuelson developed in the 1940s. In this "most iconic diagram in macroeconomics" [8] (p. 54), Samuelson emphasised that income's circular flows are based on the interdependence of production and consumption and that governments re-injects tax moneys as public spending.

28. Pierson, C. Beyond the Welfare State? The New Political Economy of Welfare, 3rd ed.; Polity Press: Cambridge, UK, 2006.

29. Kettunen, P. The society of virtuous circles. In Models, Modernity and the Myrdals, 1st ed.; The Renvall Institute for Area and Cultural Studies; Kettunen, P., Eskola, H., Eds.; University of Helsinki: Helsinki, Finland, 1997; pp. 153-173. 
30. Kuusi, P. Social Policy for the Sixties: A Plan for Finland; Finnish Social Policy Association: Helsinki, Finland, 1964.

31. Keynes, J.M. The General Theory of Employment, Interest and Money, 3rd ed.; MacMillan and Co.: London, UK, 1936.

32. However, the relationship between the plans and empirical implications is weaker than often expected. When Juho Saari (1997) compared the developments that Kuusi predicted with the reforms that actually took place in the Finnish welfare state after Kuusi's book was published, he found that "factors other than plans or scholars have determined the structure of social policy in industrialising countries" (ibid., 150). Saari, J. In Gunnar Myrdal's footsteps: Pekka Kuusi and the vision of scientific planning. In Models, Modernity and the Myrdals, 1st ed.; The Renvall Institute for Area and Cultural Studies; Kettunen, P., Eskola, H., Eds.; University of Helsinki: Helsinki, Finland, 1997; pp. 129-152.

33. Spash, C.L.; Schandl, H. Challenges for Post Keynesian growth theory: Utopia meets environmental and social reality. In Post Keynesian and Ecological Economics: Confronting Environmental Issues, 1st ed.; Holt, R.P., Pressman, S., Spash, C.L., Eds.; Edward Elgar: Cheltenham, UK, 2009; pp. 47-76.

34. Campbell, J.L. Institutional analysis and the role of ideas in political economy. Theory Soc. 1999, 27, 377-409. [CrossRef]

35. Lehtonen, H. Sosiaalipolitiikka Moraalitaloutena; Social Policy As Moral Economy; Gaudeamus: Helsinki, Finland, 1996.

36. Gough, I. Welfare states and environmental states: A comparative analysis. Environ. Politics 2016, $25,24-47$. [CrossRef]

37. Hall, P. Policy paradigms, social learning, and the state: The case of economic policymaking in Britain. Comp. Politics 1993, 25, 275-296. [CrossRef]

38. Muraca, B. Towards a fair degrowth-society: Justice and the right to a 'good life' beyond growth. Futures 2012, 44, 535-545. [CrossRef]

39. Krueger, R.; Schulz, C.; Gibbs, D.C. Institutionalizing alternative economic spaces? An interpretivist perspective on diverse economies. Prog. Hum. Geogr. 2018, 42, 569-589. [CrossRef]

40. Daly, H.E. Beyond Growth: The Economics of Sustainable Development; Beacon Press: Boston, MA, USA, 1996.

41. Barnosky, A.D.; Brown, J.H.; Daily, G.C.; Dirzo, R.; Ehrlich, A.H.; Ehrlich, P.R.; Eronen, J.T.; Fortelius, M.; Hadly, E.A.; Leopold, E.B.; et al. Introducing the scientific consensus on maintaining humanity's life support systems in the 21st century: Information for policy makers. Anthr. Rev. 2014, 1, 78-109.

42. IPCC. Intergovernmental Panel on Climate Change. Global Warming of $1.5^{\circ} \mathrm{C}$ : An IPCC Special Report; IPCC: Geneva, Switzerland, 2018.

43. Schandl, H.; Hatfield-Dodds, S.; Wiedmann, T.; Geschke, A.; Cai, Y.; West, J.; Newth, D.; Baynes, T.; Lenzen, M.; Owen, A. Decoupling global environmental pressure and economic growth: Scenarios for energy use, materials use and carbon emissions. J. Clean. Prod. 2016, 132, 45-56. [CrossRef]

44. Gough, I. Heat, Greed and Human Need: Climate Change, Capitalism and Sustainable Wellbeing, 1st ed.; Edward Elgar: Cheltenham, UK, 2017.

45. Steffen, W.; Rockström, J.; Richardson, K.; Lenton, T.M.; Folke, C.; Liverman, D.; Summerhayes, C.P.; Barnosky, A.D.; Cornell, S.E.; Crucifix, M.; et al. Trajectories of the earth system in the Anthropocene. Proc. Natl. Acad. Sci. USA 2018, 115, 8252-8259. [CrossRef] [PubMed]

46. Koch, M. The state in the transformation to a sustainable postgrowth economy. Environ. Politics 2019, 29, 115-133. [CrossRef]

47. Hausknost, D. The environmental state and the glass ceiling of transformation. Environ. Politics 2019. [CrossRef]

48. Kettunen, P.; Petersen, K. Introduction: Rethinking welfare state models. In Beyond Welfare State Models: Transnational Historical Perspectives on Social Policy, 1st ed.; Kettunen, P., Petersen, K., Eds.; Edward Elgar: Cheltenham, UK, 2011; pp. 1-15.

49. Hirvilammi, T.; Helne, T. Changing paradigms: A sketch for sustainable wellbeing and ecosocial policy. Sustainability 2014, 6, 2160-2175. [CrossRef]

50. Koch, M.; Mont, O. Sustainability and the Political Economy of Welfare; Routledge: London, UK; New York, NY, USA, 2016.

51. Cosme, I.; Santos, R.; O'Neill, D.W. Assessing the degrowth discourse: A review and analysis of academic degrowth policy proposals. J. Clean. Prod. 2017, 149, 321-334. [CrossRef] 
52. Helne, T.; Hirvilammi, T. Having, doing, loving, being: Sustainable well-being for a post-growth society. In Towards a Political Economy of Degrowth, 1st ed.; Chertkovskaya, E., Paulsson, A., Barca, S., Eds.; Rowman \& Littlefield: Lanham, MD, USA, 2019; p. 225.

53. Di Giulio, A.; Fuchs, D. Sustainable consumption corridors: Concept, objections, and responses. GAIA Ecol. Perspect. Sci. Soc. 2014, 23, 184-192. [CrossRef]

54. Gibson-Graham, J.K.; Roelvink, G. The nitty gritty of creating alternative economies. Soc. Altern. 2011, 30, 29-33.

55. Eisler, R. The Real Wealth of Nations: Creating A Caring Economics; Berrett-Koehler: San Francisco, CA, USA, 2008.

56. Büchs, M.; Koch, M. Challenges for the degrowth transition: The debate about wellbeing. Futures 2019, 105, 155-165. [CrossRef]

57. Hildingsson, R.; Kronsell, A.; Khan, J. The green state and industrial decarbonisation. Environ. Politics 2019, 28, 909-928. [CrossRef]

58. Holt, R.P.; Spash, C.L. Post Keynesian and ecological economics: Alternative perspectives on sustainability and environmental economics. In Post Keynesian and Ecological Economics: Confronting Environmental Issues, 1st ed.; Holt, R.P., Pressman, S., Spash, C.L., Eds.; Edward Elgar: Cheltenham, UK, 2009; pp. 3-25.

59. D'Alessandro, S.; Dittmer, K.; Distefano, T.; Cieplinski, A. Eurogreen Model of Job Creation in A Post-Growth Economy. The Greens and EFA in the European Parliament. 2018. Available online: https:/drive.google.com/ file/d/0B5L61s7LfvFNanFYTHdXdDhXam96VHJiWjk0NWIDU1ZVNnZv/view (accessed on 10 December 2019).

60. Järvensivu, P.; Toivanen, T.; Vadén, T.; Lähde, V.; Majava, A.; Eronen, J.T. Governance of Economic Transition. Global Sustainable Development Report 2019 Drafted by the Group of Independent Scientists. Invited Background Document on Economic Transformation, To Chapter: Transformation: The Economy. 2018. Available online: https://bios.fi/bios-governance_of_economic_transition.pdf (accessed on 8 November 2019).

(C) 2020 by the author. Licensee MDPI, Basel, Switzerland. This article is an open access article distributed under the terms and conditions of the Creative Commons Attribution (CC BY) license (http://creativecommons.org/licenses/by/4.0/). 